\title{
Potential determinants of students' academic success in private tertiary education in South Africa
}

\author{
Riley Carpenter \\ Tracy Kraus \\ College of Accounting, University of Cape Town, South Africa
}

\begin{abstract}
Key Words
Academic performance, accounting students, determinants of success, higher education, South Africa, private tertiary education
\end{abstract}

\begin{abstract}
Racial transformation is essential for the South African accounting profession. Consequently, adequate support is required for students pursuing the chartered accountant (CA(SA)) designation. This study examines determinants of success in private tertiary institutions in South Africa. The variables considered are demographic details (age, gender, and race), prior academic performance, prior tertiary institution, previous attempts, time lapses between undergraduate and postgraduate study, class format selection, use of technology and mentorship. While this study reviews prior work on private higher education, it is also innovative as it extends existing research by considering several variables which have not been investigated before in South Africa. The findings highlight the need for further empirical research on the determinants of success in private tertiary education to better support accounting students.
\end{abstract}

\section{Introduction}

In recent years there has been growing awareness in South Africa of the need for racial transformation of the accounting profession. Consequently, efforts have been made in the higher education sphere to assist promising students from a diverse range of ethnicities to pursue a professional accounting career. This is imperative, not only for the economic stability of the nation but also to promote equality and rectify the injustices of South Africa's past. While established residential universities have made considerable headway in this regard, private education providers also need to make a concerted effort in this field.

South Africa has made significant progress in tertiary education in recent years, including the increase in students attending university, particularly Black South Africans (South African Institute of Race Relations, 2019). However, this has not translated into equitable academic success, as measured by graduation rates (Neethling, 2015). The Department of Higher Education and Training (2014) uses the composite term 'Black' to refer to the racial descriptors of African, Coloured and Indian/Asian. Coupled with White, these racial descriptors are used for planning, monitoring, and funding in South Africa.

It is paramount to identify the factors affecting students' academic success in order to determine which students require support, how best to implement that support and when to start providing the support. Moreover, understanding success factors could also be used to assess the application of programmes and the allocation of available capacity to students at-risk. It may also provide a way of supporting students who would otherwise be deprived of the opportunity to pursue their accounting qualification.

If access to professional accounting qualifications can be widened to accommodate those previously excluded through innovative programme structure and the provision of additional support (financial and otherwise), it is hoped these measures will be translated into more equitable success in the country.

Private accounting programmes in South Africa are relatively new entrants onto the accounting education market. Consequently, there is limited research on such programmes in the country compared to established public universities. When investigating factors that lead to students' academic success, the private education sector provides a platform for considering variables that have received little or no research attention. These include prior tertiary institution, previous attempts at the programme, time lapse after undergraduate degree, daytime, or after-hours classes, use of technology and mentorship. 
Using a directed content analysis of literature within the framework of Biggs' 3P model, this paper explores the determinants of student academic success in private tertiary institutions in South Africa.

Three research questions are addressed: (1) Why is it important to understand the factors affecting students' academic success? (2) How can the factors affecting student success be categorised? (3) What are the factors affecting students' academic success in South Africa, as reported in the literature?

This paper begins by considering why student success is important. Thereafter the research topic is contextualised within the theoretical framework of Biggs' 3P model, explaining how three sets of factors incorporate the determinants of success. Specific factors affecting students' academic success are then examined, focusing on private tertiary education. The conclusion, with limitations and areas for future research, wraps up the paper.

\section{Methodology}

Directed content analysis was used to consider potential determinants of academic success in private tertiary institutions in South Africa. While the goal of directed content analysis is usually to extend theory (Hsieh and Shannon, 2005), in this case, prior literature was used to collate, summarise and analyse studies to inform future research questions.

The sample selection began with an online search of the Google Scholar and University of Cape Town library databases. All works on determinants of academic success were identified and the abstracts were scrutinised for relevance. The final selection was then reviewed in terms of the three research questions.

\section{Literature Review}

\subsection{Importance of understanding student academic success factors}

In recent years, higher education institutions have made concerted efforts to improve their graduate rates. Consequently, research has focused on factors affecting either academic performance or degree completion. However, it has proven more difficult to measure certain academic success factors, notably, students' attitudes, strategies, skills and behaviours, which cannot be ascertained through grading, scores or standardised testing (Fook and Sidhu, 2015; York, Gibson and Rankin, 2015).

Frequently, researchers have measured success through students' academic performance, including achieving or exceeding a specified grade or grade point average (Letkiewicz, Lim, Heckman, Bartholomae, Fox and Montalto, 2014; Treviño, Scheele and Flores, 2014; Yue and Fu, 2017), credit accumulation (Denning, 2017; Donhardt, 2013), degree completion (Arendt, 2013; Murray, 2014) or time to completion (Letkiewicz et al., 2014; Yue and Fu, 2017). However, measuring student outcomes is limited in its approach. To be more comprehensive, other studies have expanded the variables to include students' personal development and integration into an institution's environment such as locus of control (Callaghan and Papageorgiou, 2015; Carpenter and Kunaka, 2018), student engagement (Zumbrunn, McKim, Buhs and Hawley, 2014), self-efficacy (Shamsoodien and Carpenter, 2020) or institutional culture (Lewin and Mawoyo, 2014).

To develop targeted interventions to assist students, it is paramount to first identify the determinants of academic success.

\subsection{Biggs' 3P Model}

Many factors could affect students' academic success in tertiary education. Biggs' 3P Model of student learning describes three sets of factors affecting student performance: (i) presage, (ii) process and (iii) product or performance (Biggs, 1985, 1987a, 1987b). The model has been used extensively in accounting education (Davidson, 2002; Papageorgiou, 2017; Pullen, Toerien and Anthony, 2015) as well as in other fields, for example, in educational psychology (Dart, Burnett, Purdie, Boulton-Lewis, Campbell and Smith, 2000; Zhang, 2000) and interprofessional collaboration (Freeth and Reeves, 2004).

Presage factors are independent of the learning environment. They include personal factors (e.g., intelligence, background, or demographics) or situational factors (e.g., subject content or course structure). Process factors relate to the student's study approach, which can be a surface, achieving or deep approach. Performance or product factors can be either cognitive (high-level informational structures or detailoriented) or affected (how the student experiences learning) (Biggs, 1985). 
Biggs (1987a) work mainly focuses on the learning approach adopted by students, although he does indicate that presage factors can be largely responsible for the development of the learning approach. Therefore, factors such as age, language, race, and locus of control determine the students' learning approach, which then affects their academic performance.

\subsection{Typically researched personal presage factors}

Substantial research has been performed in South Africa and internationally on student endogenous factors and their effect on academic performance at an undergraduate level. Factors identified include age, gender, race, home language, whether accounting was selected as a Grade 12 subject, performance in Grade 12 accounting, performance in Grade 12 mathematics and overall Grade 12 performance. However, there is limited research on factors affecting accounting performance at a postgraduate level or in professional accounting exams, let alone in private tertiary institutions.

\subsubsection{Age}

Studies at various South African higher education institutions on the impact of age on academic performance largely conclude that younger students outperform older students at both undergraduate level (Bokana and Tewari, 2014; Jansen and de Villiers, 2016; Müller, Prinsloo and du Plessis, 2007) and postgraduate level (de Hart, Doussey, Swanepoel, van Dyk, de Clercq and Venter, 2011; Steenkamp, 2014; Ungerer, Becker, Nieuwoudt, Swart and Wilcocks, 2013). Ungerer et al. (2013) found that students under 25 were 1.6 times more likely to pass their postgraduate accounting programme at Unisa on their first attempt than older students. A younger age is also significantly positively correlated with performance in the South African Institute of Chartered Accountants (SAICA) exams and other similar professional exams (Le Roux, 2017; Roos, 2009; van Wyk, 2011). This may be due to additional family commitments and responsibilities which older students bear (Aboo, 2017; de Hart et al., 2011). In contrast, other studies conclude that age does not significantly influence performance at an undergraduate level (Papageorgiou, 2017) or that it does so only towards the end of undergraduate studies (Papageorgiou and Halabi, 2014).

A similar pattern emerges in the limited international research available. Koh and Koh (1999) in Singapore indicate that younger students outperformed their older counterparts in an undergraduate accounting degree. This is corroborated by Deschacht and Goeman (2015) in Belgium. Younger students have also been shown to perform better in professional accounting exams by Rodrigues, Pinho, Bugarim, Craig and Machado (2018) in Brazil. In contrast, Guney (2009) note that the older students perform better in an accounting undergraduate programme in the United Kingdom (UK) while Douglas (2017) reports no significant relationship between age and performance in professional accounting exams in Scotland.

\subsubsection{Gender}

There are contradictory findings related to the impact of gender on accounting academic performance. Both Jansen and de Villiers (2016) and Tewari (2015) indicate that male students outperform female students in undergraduate accounting courses at South African universities. However, Coetzee, Janse van Rensburg and Schmulian (2016) report the opposite in their study on the comprehension of the International Financial Reporting Standards among undergraduate students at a South African university. Similarly, both Le Roux (2017) and Roos (2009) indicate that females perform better in professional accounting exams. Yet other studies have found no correlation between gender and academic performance at other institutions (Bokana and Tewari, 2014; de Hart et al., 2011; Papageorgiou, 2017; Papageorgiou and Halabi, 2014; Steenkamp, 2014) or in South African professional accounting exams (van Wyk, 2011).

Males were shown to outperform females at undergraduate level in Singapore (Koh and Koh, 1999) and in professional exams in Brazil (Rodrigues et al., 2018). However, females perform better in professional accounting exams in Malaysia (Ismail, Mohammed, Ahmad and Yatim (2017), mirroring the findings of Douglas (2017) in Scotland. Overall, however, most international research concludes that gender is not significantly correlated with accounting academic performance (Byrne and Flood, 2008; Byrne, Flood and Griffin, 2014; Doran, Bouillon and Smith, 1991; Guney, 2009; Thorpe, Snell, Davey-Evans and Talman, 2017). Byrne and Flood (2008) posit that this may be the consequence of a more genderbalanced world of accounting education. 


\subsubsection{Race}

Given South Africa's history of apartheid and the institutionalised disparities in educational opportunities along racial lines, it is unsurprising that there are significant differences between the academic performance of white students and that of other racial groups (Bokana and Tewari, 2014; Le Roux, 2017; Papageorgiou, 2017; Ungerer et al., 2013). Ungerer et al. (2013) reports that white students in Unisa's postgraduate accounting programme were 2.2 times more likely to pass than Coloured or Indian students and 2.8 times more likely to pass than Black students. Sartorius and Sartorius (2013) note that Black students consistently underperformed in the old version of the first professional accounting exam during 2005-2010 compared to other races, although the performance gap slightly lessened over the period under review. Le Roux (2017) indicate that Black candidates are over four times more likely to fail the second professional accounting exam than white candidates. Barac (2015) stresses that the lack of workplace readiness and social support structures plays a significant role in failure in the old version of South Africa's second professional accounting exam.

Despite intensive efforts within the first two decades of South Africa's democracy in 1994 to widen tertiary access and provide student funding, student attrition rates remain high and throughput remains low (Kaburise, 2014). Substantial change is only likely once adjustments are made at either end of the tertiary education 'pipeline', by addressing the deficiencies in the secondary schooling system and ensuring that employment opportunities await successful graduates (Kaburise, 2014). Moreover, funding and financial aid play an important role in graduation rates and time-to-completion (Carpenter and Roos, 2020).

There is scant international research on the link between race and accounting academic performance, perhaps reflecting the lack of diversity in other countries compared to South Africa. Where such research exists, the results have been varied and inconclusive (Douglas, 2017; Guney, 2009).

\subsubsection{Language}

Linked to the impact of race on academic performance is that of home language. In South Africa, tertiary education is offered in only English and Afrikaans, just two of the nation's 11 official languages (van Wyk, 2011). Research suggests that a strong positive correlation exists between academic success and assessment in one's first language (Bokana and Tewari, 2014; de Hart et al., 2011; Papageorgiou, 2017; Steenkamp, 2014; Swart and Becker, 2014). Ungerer et al. (2013) report that Unisa students assessed in their home language are $30 \%$ more likely to pass a postgraduate accounting programme at their first attempt than those who assessed in another language. In contrast, numerous studies note that Grade 12 language marks are not correlated with academic success at university. This is confirmed by Aboo (2017) at Unisa, Jansen and de Villiers (2016) at the University of the Western Cape and van Rooy and Coetzee-van Rooy (2015) at North-West University. At the University of the Western Cape, Pullen et al. (2015) indicate that while having English as a first language is not associated with success for undergraduate students enrolled in management accounting courses, it is of statistical significance at postgraduate level. They posit that this may be due to the greater requirement for interpretation and application of key principles in unfamiliar scenarios at postgraduate level, suggesting that home language may contribute to success at postgraduate level even if it plays an insignificant role at undergraduate level. Additionally, van Wyk (2011) found a strong positive correlation between students who were successful in South Africa's first professional accounting exam and those with Afrikaans or English as their first language (who were therefore able to sit the exam in their first language).

Interestingly, multilinguism may actually contribute to academic success (Martirosyan, Hwang and Wanjohi, 2015; Papageorgiou, 2017), which could apply to many South African students who are fluent in several languages. However, Rossouw (2018) found that more than a third of undergraduate Afrikaans accounting students would consider changing to English as their language of instruction.

\subsubsection{Grade 12 subject selection and results}

A number of studies report that students who took accounting as a subject in Grade 12 outperform those who did not have Grade 12 accounting in first-year accounting courses (Bokana and Tewari, 2014; Papageorgiou, 2017; Papageorgiou and Carpenter, 2019; Yanbarisova, 2014). This is supported by some international studies (Byrne and Flood, 2008) and contradicted by others (Douglas, 2017; Koh and Koh, 
1999). It should, however, be noted that any advantage gained from selecting accounting in high school does not endure beyond the first year of undergraduate study, both in South Africa (Jansen and de Villiers, 2016; Papageorgiou and Halabi, 2014) and internationally (Doran, Bouillon and Smith, 1991), presumably as the content of second- and third-year accounting courses becomes more advanced.

Performance in Grade 12 mathematics has also been positively correlated with performance in South African undergraduate accounting courses (Bokana and Tewari, 2014; Papageorgiou and Halabi, 2014; Swart and Becker, 2014; Tewari, 2015). This is supported by Guney (2009) in the UK, Koh and Koh (1999) in Singapore and Ismail et al. (2017) in Malaysia. However, this correlation also declines towards the end of undergraduate studies and at postgraduate level (Jansen and de Villiers, 2016; Pullen et al., 2015).

Overall performance in Grade 12 is strongly correlated with academic success at all levels of tertiary education (Bokana and Tewari, 2014; Jansen and de Villiers, 2016; Pullen et al., 2015). However, van Rooy and Coetzee-van Rooy (2015) indicate that Grade 12 results are a strong predictor of success at university only for students who achieve an average of $65 \%$ or more. The prediction value of Grade 12 results is much weaker for students who achieve an average of less than $65 \%$; some of these students go on to perform well at tertiary level while others fail. A possible explanation may be that other, more qualitative factors such as grit, motivation and maturity play a larger role in determining whether more marginal students succeed.

\subsubsection{Prior academic performance}

Numerous studies affirm that the single best predictor of academic performance at every level is academic performance in the immediately preceding year of study. This has been confirmed in South African undergraduate courses (Jansen and de Villiers, 2016; Papageorgiou and Halabi, 2014; Swart and Becker, 2014), postgraduate courses (Pullen et al., 2015; Steenkamp, 2014; Swart and Becker, 2014) and professional exams (Dehrmann, 2013; van Wyk, 2011). Thus, progression requirements applied by most South African universities appear justified, as these tend to consider the most recent academic performance in determining whether students qualify to progress. The reason that prior performance is so strongly linked to academic success is likely due to the hierarchical knowledge structure applicable in an accounting context (Myers, 2017). These findings are confirmed by international research, both at university level (Archambault and Archambault, 2016; Byrne and Flood, 2008; Doran, Bouillon and Smith, 1991; Koh and Koh, 1999; Maksy and Wagaman, 2016) and in professional exams (Douglas, 2017; Rodrigues et al., 2018).

\subsection{Additional personal presage factors}

This paper not only considers existing research but also expands on prior literature by contemplating hitherto unexplored presage factors. These include the institution at which the student's prior tertiary studies were undertaken; whether any time elapsed between the completion of the undergraduate degree and the commencement of the accounting postgraduate programme; and whether a postgraduate accounting programme had previously been attempted.

\subsubsection{Prior tertiary institution}

Most research on postgraduate studies has considered students at a single university (Papageorgiou, 2017; Pullen et al., 2015; Steenkamp, 2014). Where distinctions have been made as to undergraduate institution, these have typically divided students into those who progressed through a given university and those who did not. For instance, in comparing the postgraduate accounting programme performance of students at the University of KwaZulu Natal (UKZN), Murray (2017) noted that those who had completed their undergraduate degree at UKZN performed significantly better than those who had done so at another university.

Although some universities accept students into a postgraduate accounting programme from other undergraduate institutions, given its nationwide accessibility, Unisa appears to be the only public programme to accept students from a wide range of undergraduate backgrounds. It is therefore well positioned to compare the performance of students from different undergraduate institutions. However, most research on accounting programmes at Unisa divides students into those who completed their undergraduate studies at Unisa and those who did so at other institutions (Sadler and Erasmus, 2005; 
Swart and Becker, 2014; Ungerer et al., 2013). This is despite the fact that the majority of Unisa postgraduate accounting students completed their undergraduate degrees full-time at other institutions (Aboo, 2017). The fact that Unisa provides solely distance education also introduces unique risks and places additional demands on students (Aboo, 2017; de Hart et al., 2011; Ungerer et al., 2013).

Research by Rodrigues et al. (2018) across the breadth of Brazil found a significant positive relationship between students' performance in professional accounting exams and the higher education institution at which they graduated. In fact, they found that prior higher education institution was even more strongly correlated with success in professional exams than prior academic performance. This highlights the value of similar research in a South African context.

\subsubsection{Previous attempts and time lapses after undergraduate degree}

For students pursuing the CA(SA) designation, non-academic factors such as geographical location, financial resources and marital status may play a significant role either in aiding or obstructing eventual success (Aboo, 2017; Carpenter and Roos, 2020; Roos, 2009). Such factors may result in students pausing along their path to qualification. They may also contribute to poor performance, requiring repetition of steps along the way.

In South Africa, there is scant research on the impact of multiple attempts at a postgraduate accounting programme or time lapses following completion of undergraduate studies on ultimate academic success in postgraduate accounting education or on the first professional accounting exam. Pullen et al. (2015) observes that students attempting the University of the Western Cape's postgraduate management accounting for the first time are more likely to succeed than those repeating the course. Furthermore, van Wyk (2011) notes a strong negative correlation between the length of time taken to complete both undergraduate and postgraduate studies and performance in the first professional accounting exam. van Wyk (2011) also indicates that candidates' chances of success in the first professional accounting exam are the highest at their first attempt and decrease with each additional attempt. This is supported by Sartorius and Sartorius (2013), who note that the chances of success in the first professional accounting exam are significantly reduced for students attempting the exam a second time or for those who take more than one year to complete the postgraduate accounting programme or write supplementary exams.

International studies have noted that the timing of courses may influence academic success. Archambault and Archambault (2016) identify a negative correlation between the time taken to complete a sophomore undergraduate course and academic performance in a senior undergraduate course at Marshall University in West Virginia. Surprisingly, Douglas (2017) notes that students who do not progress directly from university to their training contracts perform better in one of the professional accounting exams in Scotland, though only significantly so in financial reporting.

In summary, it appears that the longer it takes accounting students to successfully complete any leg of their academic journey, the less likely they are to reach their ultimate goal.

\subsection{Situational presage factors}

\subsubsection{Class format selection}

Situational presage factors include class format selection (i.e. whether the student engaged on a daytime (full contact) or after-hours (blended learning) track). Asarta and Schmidt (2017) define blended learning as ranging from small amounts of online material in a traditional classroom to purely online courses with no face-to-face interaction.

For private tertiary institutions offering this selection, the daytime cohorts would be exposed to a traditional, face-to-face, fully contact environment. The after-hours cohort would view all lectures as online recordings and only receive limited in-person contact sessions. Therefore, engagement through differing modes may influence academic performance.

Much international research has compared the performance of students in traditional learning environments to those exposed to a blended learning approach. Most findings reveal no statistically relevant difference (Aly, 2016; Baepler, Walker and Driessen, 2014), while others report that blended learning may actually improve performance (Vo, Zhu and Diep, 2017). However, when analysing the effect of learning mode against prior academic performance, Asarta and Schmidt (2017) note that stronger 
students perform significantly better in a blended learning environment while weaker students perform significantly better in traditional classrooms. Mid-range students' performance remains unaffected. Deschacht and Goeman (2015) reveal that although blended learning has no significant effect on exam performance in general, there is a negative effect on exam performance in accounting courses. They conclude that this may be related to how blended learning was implemented in those particular courses.

Students' reasons for selecting the after-hours format over the daytime format may also influence their eventual performance. For example, some full-time students may choose to attend after-hours courses to keep active studying hours free during the day while working students would only be able to attend evening courses due to work commitments during the day. Surprisingly, research at Unisa has found that part-time students outperform full-time students at both undergraduate (de Hart et al., 2011) and postgraduate level (Müller, Prinsloo and Plessis, 2007). Maksy and Wagaman (2016) concur, finding no negative association between working students and academic performance in Pennsylvania.

\subsubsection{Use of technology}

Several aspects of private tertiary accounting programmes differentiate them from other postgraduate accounting programmes in South Africa. The first is the widespread use of technology to streamline and modernise education. For example, at one institution, a mobile app was developed for students to record lecture and tutorial attendance; all assessments were scanned and marked; and social media was used to foster community among students and with lecturing staff (CA Connect, 2014). At Unisa, de Hart et al. (2011) indicate that integration with technology leads to a highly statistically significant improvement in student results. Therefore, extensive application of innovative technology in private tertiary accounting programmes is expected to improve performance.

\subsubsection{Mentorship}

Another distinguishing factor of private tertiary accounting programmes is the use of mentorship programmes to provide individualised, non-academic support to students (CA Connect, 2014). In the initial years of one such programme, students were asked to select a member of staff to act as their mentor. In 2017, this was extended, with alumni volunteering to mentor students, sharing insights into helpful studying approaches, and providing emotional support and encouragement. The ability to provide individualised mentorship may be due to the increased resources and lower student numbers in private institutions - for example, the Institute of Accounting Science had 159 students and Monash had 88 students write the first professional accounting exam in January 2020 while Unisa (distance-learning only) had 1,294 and University of Cape Town (largest residential university) had 375 students (SAICA, 2020). Social support plays an important role in student performance (Barac, 2015); therefore it is expected that mentorship would influence success in accounting programmes and professional exams.

\section{Conclusion}

This paper highlighted the importance of understanding factors affecting accounting students' academic success in private tertiary education. Cognisance of these factors will help universities devise more effective strategies.

According to Biggs' 3P model, many presage factors affect academic performance, namely, age, gender, race, language, and prior academic results. Because this study considered private institutions, additional presage factors included prior tertiary institution, number of previous attempts, time lapses between undergraduate and postgraduate degrees, class format selection, the use of technology and mentorship.

To date, South African research on determinants of success has concentrated on traditional universities, and not private tertiary institutions. All students seeking to qualify as CAs (SA) face an onerous qualification path. But for some, this journey is fraught with greater challenges. The onus is on educators to use the insights and technology at their disposal to offer meaningful interventions. Further research on this topic will assist educators and higher education institutions to tailor programmes to better support accounting students, thereby aiding transformation. 


\section{Limitations and areas for future research}

The scope of this paper is limited to a literature review. Future research should empirically examine the factors identified as significantly affecting the academic performance of accounting students in private tertiary education, specifically in South Africa.

\section{References}

Aboo, F. (2017) Non-academic factors contributing towards performance of postgraduate open distance learning accounting students. University of South Africa.

Aly, I. (2016) 'Comparison of Students' Performance in a Managerial Accounting Course Taught in Blended Learning, Traditional Classroom \& Online Setting', Quarterly Review of Business Disciplines, 2(4), pp. 325-336.

Archambault, M. and Archambault, J. (2016) 'Senior Level Accounting Course Performance and the Timing of Completing Intermediate Accounting II', International Journal of Accounting and Taxation, 4(2), pp. 12-24.

Arendt, J. N. (2013) 'The effect of public financial aid on dropout from and completion of university education: Evidence from a student grant reform', Empirical Economics, 44(3), pp. 1545-1562.

Asarta, C. J. and Schmidt, J. R. (2017) 'Comparing student performance in blended and traditional courses: Does prior academic achievement matter?', Internet and Higher Education, 32, pp. 29-38.

Baepler, P., Walker, J. D. and Driessen, M. (2014) 'It's not about seat time: Blending, flipping, and efficiency in active learning classrooms', Computers and Education, 78, pp. 227-236.

Barac, K. (2015) 'Helping Disadvantaged Students: Findings from the Thuthuka Programme', Accounting Education, 24(2), pp. 75-101.

Biggs, J. B. (1985) 'The role of metalearning in the study processes', British Journal of Educational Psychology, 55(2), pp. $185-212$.

Biggs, J. B. (1987a) Student approaches to learning and studying. Research Monograph, Australian Council for Educational Research. Available at: https://eric.ed.gov/?id=ED308201 (Accessed: 2 March 2020).

Biggs, J. B. (1987b) Study Process Questionnaire Manual. Student Approaches to Learning and Studying, Australian Coucil for Education Research.

Bokana, K. G. and Tewari, D. D. (2014) 'Determinants of Student Success at a South African University: An Econometric Analysis', Anthropologist, 17(1), pp. 259-277.

Byrne, M. and Flood, B. (2008) 'Examining the relationships among background variables and academic performance of first year accounting students at an Irish University', Journal of Accounting Education, 26(4), pp. 202-212.

Byrne, M., Flood, B. and Griffin, J. (2014) 'Measuring the Academic Self-Efficacy of First-year Accounting Students', Accounting Education, 23(5), pp. 407-423.

CA Connect (2014) 2014 Programme Information.

Callaghan, C. and Papageorgiou, E. (2015) 'Gender differences in locus of control and student performance in the South African context of accounting studies', Meditari Accountancy Research, 23(3), pp. 348-368.

Carpenter, R. and Kunaka, S. (2018) 'Gender-differentiated locus of control in a racially diverse accounting student body at a South African university', 30th Annual Conference of the Southern African Institute of Management Scientists (SAIMS), Stellenbosch, 16-19 September 2018, pp. 16-29. ISBN: 978-0-7972-1729-4. Retrieved from http://www.saibw.co.za/docs/2018Conference_Proceedings.pdf\#page=19

Carpenter, R. and Roos, L. (2020) 'Can we afford it? The association between financial aid and time to completion in accounting higher education in South Africa: A literature review', 9th International Conference on Business and Economic Development (ICBED), New York, 20-22 August 2020, pp. 222-232. DOI: https://doi.org/10.24052/BMR/V11NU01/ART-24.

Coetzee, S. A., Janse van Rensburg, C. and Schmulian, A. (2016) ‘Differences in students' reading comprehension of international financial reporting standards: A South African case', Accounting Education, 25(4), pp. 306-326.

Dart, B. C., Burnett, P.C., Purdie, N., Boulton-Lewis, G., Campbell, J. and Smith, D (2000) 'Students' conceptions of learning, the classroom environment, and approaches to learning', Journal of Educational Research, 93(4), pp. $262-270$.

Davidson, R. A. (2002) 'Relationship of study approach and exam performance', Journal of Accounting Education, 20(1), pp. 29-44.

Dehrmann, L. (2013) Predictors of examination success in the SAICA qualifying examinations. Masters Thesis, Stellenbosch University.

Denning, J. T. (2017) Born under a lucky star: Financial aid, college completion, labor supply and credit constraints, Upjohn Institute working paper, pp. 17-267.

Department of Higher Education and Training (2014) Report of the Ministerial Committee for the Review of the Funding of Universities, Government Printer, Pretoria.

Deschacht, N. and Goeman, K. (2015) 'The effect of blended learning on course persistence and performance of adult learners: A difference-in-differences analysis', Computers and Education, 87, pp. 83-89. 
Donhardt, G. L. (2013) 'The Fourth-Year Experience: Impediments to Degree Completion', Innovative Higher Education, 38(3), pp. 207-221.

Doran, B. M., Bouillon, M. L. and Smith, C. G. (1991) 'Determinants of student performance in accounting principles I and II', Issues in Accounting Education, 6(1), pp. 74-84.

Douglas, S. (2017) Does an accounting degree add up? An investigation into the professional exam performance and nontechnican skill development of accounting degree graduates. Robert Gordon University.

Fook, C. Y. and Sidhu, G. K. (2015) 'Investigating Learning Challenges Faced by Students in Higher Education', Procedia - Social and Behavioral Sciences, pp. 604-612.

Freeth, D. and Reeves, S. (2004) 'Learning to work together: Using the presage, process, product (3P) model to highlight decisions and possibilities', Journal of Interprofessional Care, 18(1), pp. 43-56.

Guney, Y. (2009) 'Exogenous and Endogenous Factors Influencing Students' Performance in Undergraduate Accounting Modules', Accounting Education, 18(1), pp. 51-73.

de Hart, K., Doussey, E., Swanepoel, A., Van Dyk, M., De Clercq, B., and Venter, J. (2011) 'Increasing throughput: Factors affecting the academic performance of entry-level undergraduate taxation students at an ODL institution in South Africa', Progressio, 33(1), pp. 171-188.

Hsieh, H.-F. and Shannon, S. E. (2005) 'Three Approaches to Qualitative Content Analysis', Qualitative Health Research, 15(9), pp. 1277-1288.

Ismail, P. M., Mohammed, N. F., Ahmad, M. and Yatim, N. (2017) 'Prior Academic Performance and Passing Professional Accounting Examinations: Empirical Evidence from Malaysia', Accounting and Finance Review, 2(2), pp. 1-8.

Jansen and de Villiers, C. (2016) 'Determinants of student performance in an accounting degree programme', South African Journal of Accounting Research, 30(1), pp. 1-28.

Kaburise, P. (2014) 'Why has Widening Access to Tertiary Education in South Africa Not Resulted in Success?', Mediterranean Journal of Social Sciences, 5(20), pp. 1309-1315.

Koh, M. Y. and Koh, H. C. (1999) 'The determinants of performance in an accountancy degree programme', Accounting Education, 8(1), pp. 13-29.

Le Roux, J. (2017) Determining the profile of a successful APC candidate. Honours Technical Report. University of Cape Town.

Letkiewicz, J., Lim, H., Heckman, S., Bartholomae, S., Fox, J. J., and Montalto, C.P. (2014) 'The Path to Graduation: Factors Predicting On-Time Graduation Rates', Journal of College Student Retention: Research, Theory E Practice, 16(3), pp. 351-371.

Lewin, T. and Mawoyo, M. (2014) Student Access and Success: Issues and Interventions in South African Universities, Cape Town, South African Institute for Advancement.

Maksy, M. M. and Wagaman, D. D. (2016) 'Factors Associated with Student Performance in Upper Level Undergraduate Accounting Courses: An Empirical Comparative Study at Commuter and Residential Schools', Journal of Applied Business and Economics, 18(5), pp. 57-79.

Martirosyan, N. M., Hwang, E. and Wanjohi, R. (2015) 'Impact of English Proficiency on Academic Performance of International Students', Journal of International Students, 5(1), pp. 60-71.

Müller, H., Prinsloo, P. and du Plessis, A. (2007) 'Validating the profile of a successful first-year accounting student', Meditari Accountancy Research, 15(1), pp. 19-33.

Murray, M. (2014) 'Factors affecting graduation and student dropout rates at the University of KwaZulu-Natal', South African Journal of Science, 110(11-12), pp. 1-6.

Murray, M. (2017) 'Exploring the relationship between entry requirements and throughput rates for honours students', South African Journal of Science, 113(9-10).

Myers, L. P. (2017). An analysis of how students construct knowledge in a course with a hierarchical knowledge structure. South African Journal of Accounting Research, 31(3), 193-211.

Neethling, L. (2015) 'The determinants of academic outcomes: A competing risks approach', Proceedings of the 2015 Conference of the Economic Society of South Africa, Cape Town, pp. 1-17.

Papageorgiou, E. (2017) 'Accounting students' profile versus academic performance: A five-year analysis', South African Journal of Higher Education, 31(3), pp. 31-3.

Papageorgiou, E. and Carpenter, R. (2019) 'Prior accounting knowledge of first-year students at two South African universities: Contributing factor to academic performance or not?', South African Journal of Higher Education, 33(6), pp. 249-264. doi:https://doi.org/10.20853/33-6-3032.

Papageorgiou, K. and Halabi, A. (2014) 'Factors contributing toward student performance in a distance education accounting degree', Meditari Accountancy Research, 22(2), pp. 211-223.

Pullen, E., Toerien, F. and Anthony, J. (2015) 'Student Endogenous Factors that Impact on Performance in Advanced Management Accounting: an Exploratory Study', Proceedings of the 2015 SAAA/IAAER Biennial Conference, pp. 604-621. 
Rodrigues, L. L., Pinho, C., Bugarim, M. C., Craig, R. and Machado, D. (2018) 'Factors affecting success in the professional entry exam for accountants in Brazil', Accounting Education, 27(1), pp. 48-71.

Roos, S. (2009) 'Factors affecting Southern African students' success in CIMA examinations', Meditari Accountancy Research, 17(1), pp. 48-67.

Rossouw, M. (2018) 'Language of instruction and its effect on the performance of accounting students', South African Journal of Higher Education, 32(2), pp. 258-272.

Sadler, E. and Erasmus, B. (2005) 'The academic success and failure of black chartered accounting graduates in South Africa: A distance education perspective', Meditari Accountancy Research, 13(1), pp. 29-50.

Sartorius, K. and Sartorius, B. (2013) 'The comparative performance of chartered accountancy students in South Africa: The impact of historical legacies', Development Southern Africa, 30(3), pp. 401-416.

Shamsoodien, S. and Carpenter, R. (2020) 'Do Beliefs Matter in Accounting? Self-efficacy and Student Academic Performance in Accounting Higher Education in South Africa: A Literature Review', in 2020 Southern African Accounting Association National Teaching and Learning and Regional Conference Proceedings in association with the Meditari Accountancy Research Conference. 2 October. Cape Town. ISBN: 978-0-620-90856-6.

South African Institute of Chartered Accountants (2020) ITC analysis of January 2020 results, Johannesburg. Available at: https://www.saica.co.za/Portals/0/documents/Part_I_ITC_Jan_2020_Final_Stats_Firms_.pdf.

South African Institute of Race Relations (2019) Free Facts: South Africa-A Qualified Success, South African Institute of Race Relations Free Facts Report, 3(11).

Steenkamp, G. (2014) 'How pre-admission characteristics affect the performance of CTA students at a South African university', Journal of Economic and Financial Sciences, 7(2), pp. 283-298.

Swart, O. and Becker, A. I. (2014) 'Matric results in mathematics and languages : A predictor of undergraduate and postgraduate success', Progressio, 36(1), pp. 157-181.

Tewari, A. R. (2015) African female students' experiences of introductyory accounting modules at UniZulu. Univerisity of Zululand.

Thorpe, A., Snell, M., Davey-Evans, S. and Talman, R. (2017) 'Improving the Academic Performance of Non-native English-Speaking Students: the Contribution of Pre-sessional English Language Programmes', Higher Education Quarterly, 71(1), pp. 5-32.

Treviño, E., Scheele, J. and Flores, S. M. (2014) ‘Beyond the Test Score: A Mixed Methods Analysis of a College Access Intervention in Chile', Journal of Mixed Methods Research, 8(3), pp. 255-265.

Ungerer, M., Becker, A., Nieuwoudt, M. J., Swart, O. and Wilcocks, J. S. (2013) 'The importance of the changing demographic profile on the success of postgraduate accounting students', South African Journal of Higher Education, 27(6), pp. 1529-1550.

Vo, H. M., Zhu, C. and Diep, N. A. (2017) 'The effect of blended learning on student performance at course-level in higher education: A meta-analysis', Studies in Educational Evaluation, 53, pp. 17-28.

van Rooy, B. and Coetzee-van Rooy, S. (2015) 'The language issue and academic performance at a South African university', Southern African Linguistics and Applied Language Studies, 33(1), pp. 31-46.

van Wyk, E. (2011) 'A Note: The SAICA Part I Qualifying Examinations: Factors that may influence candidates' success', South African Journal of Accounting Research, 25(1), pp. 145-174.

Yanbarisova, D. M. (2014) Combining University Studies with Work: Influence on Academic Achievement, doi:http://dx.doi.org/10.2139/ssrn.2535776.

York, T. T., Gibson, C. and Rankin, S. (2015) 'Defining and Measuring Academic Success', Practical Assessment, Research E Evaluation, 20(5), pp. 1-20.

Yue, H. and Fu, X. (2017) 'Rethinking Graduation and Time to Degree: A Fresh Perspective', Research in Higher Education, 58(2), pp. 184-213.

Zhang, L. F. (2000) 'University students' learning approaches in three cultures: An investigation of Biggs' 3P model', Journal of Psychology: Interdisciplinary and Applied, 134(1), pp. 37-55.

Zumbrunn, S., McKim, C., Buhs, E. and Hawley, L. R. (2014) 'Support, belonging, motivation, and engagement in the college classroom: A mixed method study', Instructional Science, 42, pp. 661-684. 